\title{
CITA
}
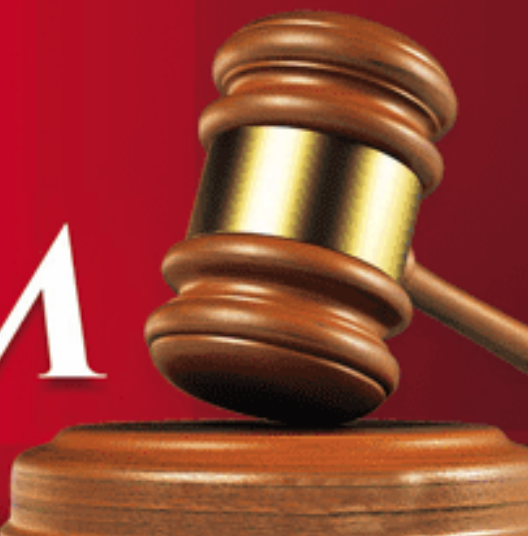

- Dewan Perwakilan Rakyat Daerah (DPRD) Dalam Perundang-undangan Pemerintahan Daerah dan Lembaga Legislatif Daerah Asmawi

- Pertanggungjawaban Penggunaan Hak Prerogatif Presiden Di Bidang Yudikatif Dalam Menjamin Kemerdekaan Kekuasaan Kehakiman Bachtiar Baital

- Praktik Pengawasan Etika DPR-RI Nur Habibi

- Fungsi Falsafah Negara Dalam Penerapan Konsep Negara Hukum Ibnu Sina Chandranegara

- THE GPH-M.I.L.F. Agreement: Human Rights Provisions and Possible Overlaps Fajri Matahati Muhammadin

- Penguatan Fungsi Pengawasan DPR Melalui Perubahan Undang-Undang No. 10 Tahun 1954 tentang Hak Angket

Fitria

- Kerangka Cita Hukum (Recht Idee) Bangsa Sebagai Dasar Kewenangan Mahkamah Konstitusi Menguji Peraturan Pemerintah Pengganti Undang-Undang (Perppu) Dedy Nursamsi

- Kedaulatan Rakyat dan Pemilihan Kepala Daerah Dalam Konteks Undang-Undang Dasar Negara Republik Indonesia tahun 1945 Sodikin 


\title{
Jurnal
}

\section{CITA HUKUM}

\section{VOL. II NO. 1 JUNI 2014}

Diterbitkan oleh Fakultas Syariah dan Hukum Universitas Islam Negeri (UIN) Syarif Hidayatullah Jakarta bekerjasama dengan Pusat Studi Konstitusi dan Legislasi Nasional (POSKO-LEGNAS) UIN

Jakarta. Jurnal Cita Hukum mengkhususkan diri dalam pengkajian Hukum Indonesia dan terbit dua kali dalam satu tahun di setiap bulan Juni dan Desember.

\author{
Redaktur Ahli \\ Muhammad Atho Mudzhar (UIN Syarif Hidayatullah Jakarta) \\ Muhammad Amin Suma (UIN Syarif Hidayatullah Jakarta) \\ Salman Maggalatung (UIN Syarif Hidayatullah Jakarta) \\ Ahmad Hidayat Buang (University Malaya Malaysia) \\ Nadirsyah Hosen (Wollongong University Australia) \\ JM Muslimin (UIN Syarif Hidayatullah Jakarta) \\ Stephen Koos (Munchen University Germany) \\ Abdullah Sulaiman (Universitas Trisakti) \\ Jimly Asshiddiqie (Universitas Indonesia) \\ Muhammad Munir (IIU Islamabad Pakisatan) \\ Tim Lindsey (Melbourne University Australia) \\ Raihanah Azahari (University Malaya Malaysia) \\ Jaih Mubarok (UIN Sunan Gunung Djati Bandung) \\ Djawahir Hejazziey (UIN Syarif Hidayatullah Jakarta)

\section{Editor in Chief} \\ Nur Rohim Yunus

\section{Managing Editor} \\ Muhammad Ishar Helmi
}

\section{Editors}

Fitria

Indra Rahmatullah

Mara Sutan Rambe

\section{Asisten to The Editors}

Erwin Hikmatiar

\section{Alamat Redaksi}

Fakultas Syariah dan Hukum UIN Syarif Hidayatullah Jakarta

Jl. Ir. H. Juanda 95 Ciputat Jakarta 15412

Telp. (62-21) 74711537, Faks. (62-21) 7491821

Website: www.fsh-uinjkt.net, E-mail: jurnal.citahukum@uinjkt.ac.id

Permalink: http://journal.uinjkt.ac.id/index.php/citahukum 


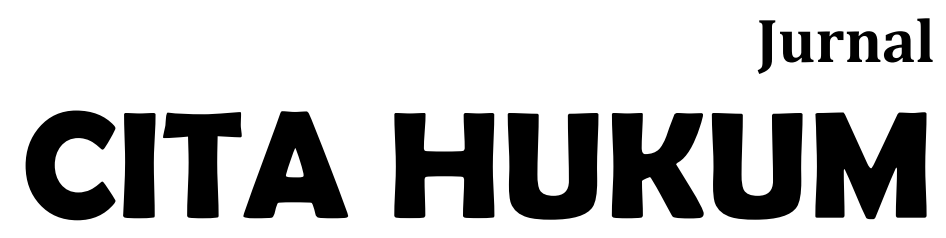

Menyambut baik kontribusi dari para ilmuwan, sarjana, profesional, dan peneliti dalam disiplin ilmu hukum untuk dipublikasi dan disebarluaskan setelah melalui mekanisme seleksi naskah, telaah mitra bebestari, dan proses penyuntingan yang ketat. 


\section{DAFTAR ISI}

1 Dewan Perwakilan Rakyat Daerah (DPRD) Dalam Perundang-undanganPemerintahan Daerah dan Lembaga Legislatif Daerah;

Asmawi

19 Pertanggungjawaban Penggunaan Hak Prerogatif Presiden Di BidangYudikatif Dalam Menjamin Kemerdekaan Kekuasaan Kehakiman;

Bachtiar Baital

39 Praktik Pengawasan Etika DPR-RI Indonesia;

Nur Habibi

53 Fungsi Falsafah Negara Dalam Penerapan Konsep Negara Hukum;

Ibnu Sina Chandranegara

67 THE GPH-M.I.L.F. Agreement: Human Rights Provisions and Possible Overlaps

Fajri Matahati Muhammadin

79 Penguatan Fungsi Pengawasan DPR Melalui Perubahan Undang-Undang No. 10 Tahun 1954 tentang Hak Angket;

Fitria

89 Kerangka Cita Hukum (Recht Idee) Bangsa Sebagai Dasar KewenanganMahkamah Konstitusi Menguji Peraturan Pemerintah Pengganti UndangUndang (Perppu);

Dedy Nursamsi

101 Kedaulatan Rakyat dan Pemilihan Kepala Daerah Dalam Konteks UndangUndang Dasar Negara Republik indonesia tahun 1945

Sodikin 
117 Kontroversi Pembentukan Perppu No. 1 Tahun 2013 Tentang Mahkamah Konstitusi Dalam Ranah Kegentingan Yang Memaksa;

Nur Rohim

133 Perkembangan Kewenangan Mengubah Undang-Undang Dasar-

Di Indonesia;

Jajang Indra Fadila

147 Pengujian Undang-Undang Ratifikasi Perjanjian Asean Charter Oleh Mahkamah Konstitusi;

Afidatussolihat

163 Eksistensi Dewan Perwakilan Daerah Dalam Sistem BikameralDi Indonesia;

Miki Pirmansyah 


\title{
Dewan Perwakilan Rakyat Daerah Dalam Perundang-Undangan Pemerintahan Daerah Dan Lembaga Legislatif Daerah*
}

\author{
Asmawi \\ Fakultas Syariah dan Hukum UIN Jakarta \\ Jl. Ir. H. Juanda No. 95 Ciputat Jakarta \\ E-mail: asmawi99@gmail.com
}

\begin{abstract}
Local People's Representative Council (DPRD) In Local Government Legislation and Regional Legislative Institutions. One of the most esential issues of democracy's results in Indonesian constitutional platform is the local legislature, so popularly known as the Local People's Representative Council (DPRD). The key of the success in organizing local government is the capability of the Local People's Representative Council (DPRD) in conducting the three basic functions and plus, namely legislating, budgeting, supervising, and plus representing, simultaneously, proportionally and continously. In the future times, it is urgent to strengthen the structure and institutional capacity of the Local People's Representative Council (DPRD) by means of three agenda, that is (i) to redefine and to consolidate the position of the Local People's Representative Council (DPRD) as a legislature; (ii) to reinforce the authority of the Local People's Representative Council (DPRD); and (iii) to maximize the capacity of the Local People's Representative Council (DPRD) in performing its all functions. To that end, it is urgent to take an effort in revising Law of 32/2004 and Law of $27 / 2009$.
\end{abstract}

Keyword: DPRD, checks and balances, UUD 1945, UU 32/2004, UU 27/2009

\begin{abstract}
Abstrak: Dewan Perwakilan Rakyat Daerah (DPRD) Dalam Perundangundangan Pemerintahan Daerah dan Lembaga Legislatif Daerah. Salah satu isu terpenting hasil demokrasi dalam pentas ketatanegaraan Indonesia ialah lembaga legislatif daerah, yang populer dikenal dengan Dewan Perwakilan Rakyat Daerah (DPRD). Kunci keberhasilan penyelenggaraan pemerintahan daerah adalah kemampuan DPRD dalam menjalankan tiga plus fungsi utamanya-legislasi, anggaran dan pengawasan, dan plus representasi-secara simultan, proporsional dan berkelanjutan. Di masa mendatang penting untuk memperkuat struktur dan kelembagaan DPRD melalui 3 (tiga) agenda: (i) memperjelas dan memperkuat kedudukan DPRD sebagai badan legislatif; (ii) memperkuat kewenangan DPRD; dan (iii) memperkuat kapasitas DPRD dalam menjalankan fungsi-fungsinya. Untuk itu, diperlukan segera upaya merevisi UU 32/2004 dan UU 27/2009.
\end{abstract}

Kata Kunci: DPRD, Checks and Balances, UUD 1945, UU 32/2004, UU 27/2009

DOI: $\underline{10.15408 / j \mathrm{jch} . v 1 \mathrm{i1} .1443}$

${ }^{*}$ Naskah diterima: 20 April 2014, direvisi: 26 April 2014, disetujui untuk terbit: 11 Juni 2014. Permalink: https://www.academia.edu/10969560 


\section{Pendahuluan}

Sejak terjadinya reformasi pada tahun 1998, tonggak sejarah baru dalam perjalanan ketatanegaraan Indonesia seolah dimulai dari awal. Mulai dari tahun 1999 hingga tahun 2002, UUD 1945 telah mengalami perubahan (amandemen) sebanyak empat kali. Dalam kerangka amandemen UUD $1945 \mathrm{itu}$, bangsa kita telah mengadopsi prinsip-prinsip baru sistem ketatanegaraan, yakni mulai dari prinsip pemisahan/pembagian kekuasaan, prinsip checks and balances, hingga prinsip supremasi hukum dalam penyelesaian 'konflik politik'. Melalui amandemen UUD $1945 \mathrm{itu}$, lahirlah sejumlah lembaga-lembaga negara, baik yang kewenangannya diberikan oleh konstitusi (constitutionally entrusted power) maupun yang yang kewenangannya diberikan oleh undang-undang (legislatively entrusted power). ${ }^{1}$

Dalam hubungannya dengan pemerintahan di daerah, prinsip demokrasi tidak boleh disederhanakan hanya berkaitan dengan pengambilan keputusan dan penyelenggaraan pemerintahan yang melibatkan peran serta masyarakat. Demokrasi juga tidak sekadar berbicara mengenai pembagian/pemisahan kekuasaan, baik antar lembaga-lembaga negara di tingkat Pusat maupun antara Pusat dan Daerah, tetapi ada sejumlah hal penting untuk diperhatikan, yakni (i) unsur-unsur dari kekuasaan, (ii) bahan baku pengambilan keputusan, dan (iii) pola hubungan antara penguasa dan rakyat. $^{2}$

Salah satu isu penting hasil demokrasi dalam pentas ketatanegaraan Indonesia ialah lembaga legislatif daerah, yang dikenal dengan Dewan Perwakilan Rakyat Daerah (DPRD). Isu DPRD sangat urgen diperbincangkan, apalagi bila diletakkan dalam bingkai prinsip checks and balances ${ }^{3}$ dan paradigma pembagian/pemisahan kekuasaan. Untuk itu, tulisan ini akan membahas sejumlah isu terkait DPRD dalam Perundang-undangan Pemerintahan Daerah dan Lembaga Legislatif Daerah, yakni (i) perundang-undangan pemerintahan daerah dan lembaga legislatif daerah, (ii) kedudukan DPRD, (iii) fungsi, tugas dan wewenang DPRD, (iv) keanggotaan DPRD, dan (v) alat kelengkapan DPRD. Tulisan diakhiri dengan "penutup" yang menegaskan pokok pikiran utama dan saran penting yang diajukan.

\section{Perundang-undangan Pemerintahan Daerah dan Lembaga Legislatif Daerah}

UUD 1945 Hasil Amandemen memuat bab khusus tentang pemerintahan daerah, yakni Bab VI (Pemerintahan Daerah) yang memiliki 3 (tiga) pasal, yaitu Pasal

\footnotetext{
${ }^{1}$ Ni'matul Huda, Hukum Tata Negara Indonesia, (Jakarta; Rajawali Press, 2005), h. vii-viii.

2 Muhammad Fauzan, Hukum Pemerintahan Daerah: Kajian tentang Hubungan Keuangan antara Pusat dan Daerah, (Yogyakarta: UII Press, 2006), h. 19.

${ }^{3}$ Diantara implikasi hasil amandemen UUD 1945 ialah diserapnya sistem/mekanisme checks and balances antara lembaga legislatif, lembaga eksekutif dan lembaga yudikatif. Dalam hubungan antara Presiden dan DPR, dominasi Presiden dalam proses legislasi digeser ke DPR; dan jika dalam waktu 30 hari sejak disahkan di DPR sebuah RUU belum ditandatangani (disahkan) oleh Presiden maka RUU tersebut sah sebagai UU dan wajib diundangkan tanpa harus ditandatangani oleh Presiden. Dalam hal hubungan antara lembaga yudikatif dan lembaga legislatif maka gagasan checks and balances mengumandangkan usul agar lembaga yudisial diberi wewenang menguji UU terhadap UUD. Ini pun diterima dan dituangkan di dalam Pasal 24 UUD 1945 yang mengatur bukan hanya pengujian isi (uji materiil) saja tapi juga pengujian prosedur (uji formiil). MK menguji UU terhadap UUD, sedang MA menguji peraturan perundangundangan di bawah UU terhadap peraturan perundang-undangan yang di atasnya. Lihat Moh. Mahfud MD, Perdebatan Hukum Tata Negara Pasca Amandemen Konstitusi, (Jakarta: LP3ES, 2007), h. 66.
} 
18, Pasal 18A, dan Pasal 18B. Ketiga pasal ini merupakan hasil amandemen kedua UUD 1945, yang disahkan pada tahun 2000. Ketiga Pasal tersebut dijadikan landasan yuridis-konstitusional bagi perundang-undangan pemerintahan daerah dan lembaga legislatif daerah.

Sepanjang sejarah ketatanegaraan Indonesia, perihal lembaga perwakilan daerah-yang sering disebut DPRD-merupakan salah satu aspek yang diatur di dalam perundang-undangan yang mengatur pemerintahan daerah. Adapun perundangundangan dimaksud meliputi: (i) UU No. 18 Tahun 1965 tentang Pokok-pokok Pemerintahan Daerah (selanjutnya disebut UU 18/1965), (ii) UU No. 5 Tahun 1974 tentang Pokok-pokok Pemerintahan di Daerah (selanjutnya disebut UU 5/1974), (iii) UU No. 22 Tahun 1999 tentang Pemerintahan Daerah (selanjutnya disebut UU 22/1999), (iv) UU No. 32 Tahun 2004 tentang Pemerintahan Daerah (selanjutnya disebut UU 32/2004), (v) PERPPU No. 3 Tahun 2005 tentang Perubahan atas UU No. 32 Tahun 2004 tentang Pemerintahan Daerah (selanjutnya disebut PERPPU 3/2005), (vi) UU No. 8 Tahun 2005 tentang Penetapan sebagai UU atas PERPPU No. 3 Tahun 2005 tentang Perubahan atas UU No. 32 Tahun 2004 tentang Pemerintahan Daerah (selanjutnya disebut UU 8/2005), dan (vii) UU No. 12 Tahun 2008 tentang Perubahan Kedua atas UU No. 32 Tahun 2004 tentang Pemerintahan Daerah (selanjutnya disebut UU 12/2008).

Di dalam UU 32/2004, pengaturan tentang DPRD dicantumkan dalam sejumlah pasal, yakni Pasal 1 angka 3, Pasal 1 angka 4, Pasal 19 ayat (2) , Pasal 2 ayat (1) ), Pasal 2 ayat (2) ), Pasal 2 ayat (3) ), Pasal 3 ayat (1) ), Pasal 3 ayat (2) ), Pasal 39, Pasal 40. Pasal 41, Pasal 42 ayat (1), Pasal 42 ayat (2), Pasal 43 ayat (1), Pasal 44 ayat (1), Pasal 45, Pasal 46 ayat (1).

Patut dicatat bahwa PERPPU 3/2005 mengubah Pasal 90 dan menambah Pasal 236A dan Pasal 236B dalam UU 32/2004. Sedangkan UU 12/2008 mengubah Pasal 26, Pasal 42, Pasal 56, Pasal 58, Pasal 59, Pasal 60, Pasal 62, Pasal 63, Pasal 64, Pasal 75, Pasal 107, Pasal 108, dan menambah ayat pada Pasal 115, menghapus Pasal 233 ayat (1), mengubah dan menambah ayat padal Pasal 233, mengubah Pasal 235 dan menambah ayat padanya, menambah Pasal 236A, 236B dan 236C, menambah Pasal 239A. Dengan demikian, sejauh terkait DPRD dalam UU 32/2004, yang tersentuh perubahan hanyalah Pasal 42 saja. Dengan demikian, sejauh terkait pemerintahan daerah, yang kini berlaku adalah UU 32/2004.

Sementara itu, serangkaian perundang-undangan yang secara khusus mengatur perihal DPRD juga telah lahir sepanjang sejarah ketatanegaraan Indonesia. Adapun perundang-undangan dimaksud mencakup: (i) UU No. 16 Tahun 1969 tentang Susunan dan Kedudukan MPR, DPR dan DPRD (selanjutnya disebut UU 16/1969), (ii) UU No. 5 Tahun 1975 tentang Perubahan UU No. 16 Tahun 1969 tentang Susunan dan Kedudukan MPR, DPR dan DPRD (selanjutnya disebut UU 5/1975), (iii) UU No. 2 ahun 1985 tentang Perubahan atas UU No. 16 Tahun 1969 tentang Susunan dan Kedudukan MPR, DPR sebagaimana telah diubah dengan UU No. 5 Tahun 1975 (selanjutnya disebut UU 2/1985), (iv) UU No. 5 Tahun 1995 tentang Perubahan atas UU No. 16 Tahun 1969 tentang Susunan dan Kedudukan MPR, DPR sebagaimana telah beberapakali diubah, Terakhir dengan UU No. 2 Tahun 1985 (selanjutnya disebut UU 5/1995), (v) UU No. 4 Tahun 1999 tentang Susunan dan Kedudukan MPR, 
DPR dan DPRD (selanjutnya disebut UU 4/1999), (vi) UU No. 22 Tahun 2003 tentang Susunan dan Kedudukan MPR, DPR, DPD, dan DPRD (selanjutnya disebut UU 22/2003), dan (vii) UU No. 27 Tahun 2009 tentang Susunan dan Kedudukan MPR, DPR, DPD, dan DPRD (selanjutnya disebut UU 27/2009). UU 27/2009-melalui Pasal 407-mencabut keberlakuan UU 22/2003; dan UU terakhir ini mencabut keberlakuan UU 4/1999; sedang UU 4/1999 ini mencabut keberlakuan UU 2/1985. Dengan demikian, yang kini berlaku hanyalah UU 27/2009.

Pada tahun 2009 disahkan UU 27/2009. Terhadap UU ini sudah dilakukan uji materiil (judicial review) di hadapan sidang Mahkamah Konstitusi. Tercatat sejak diundang-undangkan hingga Desember 2011, ada 11 (sebelas) perkara uji materiil (judicial review) atas UU 27/2009. Terhadap 11 (sebelas) perkara itu, Mahkamah Konstitusi memutus secara bervariasi. Empat perkara darinya diputus Mahkamah Konstitusi dengan amar putusan "mengabulkan".

Secara umum, pengaturan tentang DPRD terdapat dalam Bab V (DPRD Provinsi) yang memuat Pasal $290 \mathrm{~s} / \mathrm{d}$ Pasal 340 dan dalam Bab VI (DPRD Kabupaten/Kota) yang terdiri atas Pasal 341 s/d Pasal 399. Diantara pasal-pasal ini, terdapat pasal yang telah dilakukan judicial review dan diputus perkaranya oleh Mahkamah Konstitusi -seperti dikemukakan terdahulu-yakni Pasal 354 ayat (2) dan Penjelasannya, Pasal 354 ayat (3), Pasal 354 ayat (4), Pasal 354 ayat (5), Pasal 354 ayat (6), Pasal 354 ayat (7), Pasal 354 ayat (8), Pasal 354 ayat (9), Penjelasan Pasal 355 ay at (6), dan Pasal 348.

\section{Kedudukan DPRD}

Pemerintah daerah adalah Gubernur, Bupati, atau Walikota, dan perangkat daerah sebagai unsur penyelenggara pemerintahan daerah. ${ }^{4}$ Dewan Perwakilan Rakyat Daerah (DPRD) merupakan lembaga perwakilan rakyat daerah dan berkedudukan sebagai unsur penyelenggara pemerintahan daerah. ${ }^{5}$ Penyelenggara pemerintahan daerah terdiri atas pemerintah daerah dan DPRD. ${ }^{6}$

Pemerintahan daerah mencakup (a) pemerintahan daerah provinsi yang terdiri atas pemerintah daerah provinsi dan DPRD provinsi; dan (b) pemerintahan daerah kabupaten/kota yang terdiri atas pemerintah daerah kabupaten/kota dan DPRD kabupaten/kota. ${ }^{7}$ Pemerintah daerah tersebut terdiri atas kepala daerah dan perangkat daerah. ${ }^{8}$

Telah dikemukakan bahwa DPRD merupakan lembaga perwakilan rakyat daerah dan berkedudukan sebagai unsur penyelenggaraan pemerintahan daerah. ${ }^{9}$ Kedudukan DPRD sebagai unsur penyelenggara pemerintahan daerah menempatkan DPRD sebagai institusi yang sejajar dengan pemerintah daerah. Dalam kedudukan yang sejajar itu, DPRD bersama-sama dengan Kepala Daerah melaksanakan

\footnotetext{
4 Pasal 1 angka 3 UU 32/2004.

5 Pasal 1 angka 4 UU 32/2004.

${ }^{6}$ Pasal 19 ayat (2) UU 32/2004.

7 Pasal 3 ayat (1) UU 32/2004.

8 Pasal 3 ayat (2) UU 32/2004.

${ }^{9}$ Pasal 40 UU 32/2004.
}

4 - Jurnal Cita Hukum, Vol. II No. 1 Juni 2014. ISSN: 2356-1440. 
fungsi-fungsi pemerintahan daerah yang meliputi segala urusan menurut asas otonomi dan tugas pembantuan.

Perdebatan tentang isu kedudukan DPRD menyentuh pertanyaan mendasar, yakni apa "jenis kelamin" DPRD; apakah DPRD didudukan secara tegas sebagai lembaga (badan) legislatif sebagaimana dikenal dalam konsep trias politica ataukah diposisikan sebagai salah satu unsur penyelenggara pemerintahan daerah. ${ }^{10}$

Pemberian posisi DPRD sebagai badan legislatif diintrodusir oleh UU No. 22 Tahun 1999 tentang Pemerintahan Daerah (selanjutnya disebut UU 22/1999). Dalam Pasal 14 ayat (1) dinyatakan bahwa di daerah dibentuk DPRD sebagai Badan Legislatif Daerah dan Pemerintah Daerah sebagai Badan Eksekutif Daerah. Lebih dari itu, ditegaskan dalam Pasal 16 ayat (2) bahwa DPRD sebagai Badan Legislatif Daerah berkedudukan sejajar dan menjadi mitra dari Pemerintah Daerah. Di samping itu, UU 22/1999 juga mendudukkan DPRD sebagai lembaga perwakilan rakyat di daerah yang nota bene wahana untuk melaksanakan demokrasi berdasarkan Pancasila. ${ }^{11}$

Peneguhan kedudukan DPRD sebagai lembaga perwakilan rakyat-dalam bingkai UU 22/1999-diperkuat lagi dengan pemberian hak yang berbobot politik besar, yakni hak meminta pertanggungjawaban Gubernur, Bupati dan Walikota. ${ }^{12}$ Lebih dari itu, DPRD dalam melaksanakan tugasnya berhak meminta pejabat negara, pejabat pemerintah, atau warga masyarakat untuk memberikan keterangan tentang suatu hal yang perlu ditangani demi kepentingan negara, bangsa, pemerintahan, dan pembangunan. Bahkan, pejabat negara, pejabat pemerintah, atau warga masyarakat yang menolak permintaan DPRD tersebut diancam dengan pidana kurungan paling lama 1 (satu) tahun karena merendahkan martabat dan kehormatan DPRD ${ }^{13}$; dan tindakan merendahkan semacam ini dikenal dengan contempt of parliament.

Sebagian ahli mencatat bahwa penguatan posisi DPRD melalui UU 22/1999 menjadikan DPRD periode 2000-2004 sebagai fenomena legislative heavy. Dalam bingkai legislative heavy, DPRD memiliki kekuasaan dan kewenangan yang berlebih dibanding dengan yang dimiliki Gubernur, Bupati dan Walikota. Tidak jarang kondisi ini berujung pada impeachment kepala daerah di beberapa daerah, seperti Sampang-Madura. Fenomena yang demikianlah yang mendorong pemerintah dan DPR merevisi UU 22/1999, yang kemudian melahirkan UU 32/2004. Pada akhirnya UU 22/1999 kemudian dinyatakan tidak berlaku oleh Pasal 239 UU No. 32 Tahun 2004 tentang Pemerintahan Daerah (selanjutnya disebut UU 32/2004).

Revisi UU 22/1999 dilakukan untuk mengurangi dominasi DPRD atas Kepala Daerah dengan menerbitkan UU 32/2004. Rumusan kedudukan DPRD dalam UU 32/2004 mengalami perubahan sangat mendasar dan hampir mirip kembali kepada keadaan dan suasana keberlakuan UU 5/1974, tetapi tetap memberikan kewenangan dan hak yang wajar kepada DPRD dalam menjalankan fungsi pemerintahan daerah, sebagaimana disebut dalam Pasal 3 ayat (1) dan Pasal 40 UU 32/2004. Rumusan Pasal ini mirip dan mengacu pada Pasal 13 UU 5/1974. Sedangkan dalam Pasal 14 dan

\footnotetext{
${ }^{10}$ Ari Dwipayana, Arah dan Agenda Reformasi DPRD: Memperkuat Kedudukan dan Kewenangan Dewan Perwakilan Rakyat Daerah, (Jakarta: USAID, 2008), h. 20.

11 Lihat Pasal 16 ayat (1) UU 22/1999.

12 Lihat Pasal 19 ayat (1) huruf (a) UU 22/1999.

${ }^{13}$ Lihat Pasal 20 ayat (1) dan ayat (2) UU 22/1999.
}

Fakultas Syariah dan Hukum UIN Syarif Hidayatullah Jakarta - 5 
Pasal 16 UU 22/1999, DPRD disebut sebagai Badan Legislatif Daerah yang berkedudukan sejajar dan menjadi mitra Pemerintah Daerah sebagai Badan Eksekutif Daerah. Dengan lahirnya UU 32/2004, DPRD tidak lagi diposisikan sebagai lembaga legislatif daerah tetapi ditempatkan sebagai lembaga atau unsur dari pemerintahan daerah. Kendati menjadi bagian atau unsur dari pemerintahan daerah, kepada DPRD diberikan 3 (tiga) fungsi utama, yaitu fungsi legislasi, fungsi anggaran dan fungsi pengawasan. ${ }^{14}$

Seperti telah diungkapkan, di dalam UU 32/2004 diintrodusir pemberian posisi DPRD sebagai penyelenggara pemerintahan daerah. Dalam Pasal 1 angka 4 UU ini disebutkan bahwa DPRD adalah lembaga perwakilan rakyat daerah sebagai unsur penyelenggara pemerintahan daerah. Dalam Pasal 19 ayat (2) UU ini dinyatakan bahwa penyelenggara pemerintahan daerah adalah pemerintah daerah dan DPRD.

Di tengah arus kuat kritik atas fenomena legislative heavy (baca: DPRD heavy) itu, berlangsung pula proses amandemen kedua UUD 1945. Amandemen kedua UUD 1945 menghasilkan pasal-pasal yang berkaitan dengan DPRD. Dalam pasal 18 ayat (3) UUD 1945 (Hasil Amandemen Kedua) disebutkan bahwa pemerintahan daerah provinsi, daerah kabupaten dan kota memiliki Dewan Perwakilan Rakyat Daerah yang anggotaanggotanya dipilih melalui pemilihan umum. Pasal 18 ayat (6) menyatakan bahwa pemerintahan daerah berhak menetapkan peraturan daerah dan peraturan-peraturan lain untuk melaksanakan otonomi dan tugas pembantuan. Sedangkan Pasal 18 ayat (7) menegaskan bahwa susunan dan tata cara penyelenggaraan pemerintahan daerah diatur dalam undang-undang.

Tentu akan muncul pertanyaan atas rumusan pasal-pasal hasil amandemen kedua UUD 1945 tersebut, yakni apakah kalimat pemerintahan daerah provinsi, daerah kabupaten dan kota memiliki DPRD bisa diartikan sebagai upaya menegaskan DPRD sebagai salah satu unsur penyelenggara pemerintahan daerah. Paradigma DPRD sebagai unsur penyelenggara pemerintahan daerah dipromosikan oleh UU No. 22 Tahun 2003 tentang Susunan dan Kedudukan MPR, DPR, DPD dan DPRD (selanjutnya disebut UU 22/2003). ${ }^{15}$ Walaupun dalam Pasal 1 angka 4 UU 22/2003 dinyatakan bahwa Dewan Perwakilan Rakyat Daerah (DPRD) adalah Dewan Perwakilan Rakyat Daerah sebagaimana dimaksud dalam Undang-Undang Dasar Negara Republik Indonesia Tahun 1945. Namun, dalam Pasal 60 dan 76 UU 22/2003 disebutkan bahwa DPRD Provinsi dan Kabupaten/Kota merupakan lembaga perwakilan rakyat daerah yang berkedudukan sebagai lembaga pemerintahan daerah. Sementara, dalam bagian penjelasan diungkapkan bahwa yang dimaksud dengan lembaga pemerintahan daerah adalah pemerintah daerah dan DPRD yang berada di tingkat provinsi dan kabupaten/kota; sedangkan pemerintah daerah terdiri atas kepala daerah beserta perangkat daerah. Hal di atas dipertegas dengan Pasal 291 UU 27/2009 16 yang menyatakan bahwa DPRD provinsi merupakan lembaga perwakilan rakyat daerah yang berkedudukan sebagai unsur penyelenggara pemerintahan daerah provinsi.

${ }^{14}$ Nomensen Sinamo, Hukum Pemerintahan Daerah di Indonesia, (Jakarta: Pustaka Mandiri 2010), h. $47-48$.

${ }^{15}$ Berdasarkan Pasal 407 UU 27/2009, UU 22/ 2003 dicabut dan dinyatakan tidak berlaku lagi.

${ }_{16}$ UU 27/2009 ini mencabut keberlakuan UU 22/2003.

6 - Jurnal Cita Hukum, Vol. II No. 1 Juni 2014. ISSN: 2356-1440. 
Di dalam UU 32/2004, DPRD direposisi dari Badan Legislatif Daerah menjadi unsur penyelenggara pemerintahan daerah. Hal ini ditegaskan dalam Pasal 40 bahwa DPRD merupakan lembaga perwakilan rakyat daerah dan berkedudukan sebagai unsur penyelenggaraan pemerintahan daerah. Pergeseran kedudukan DPRD dari Badan Legislatif Daerah menjadi unsur penyelenggara pemerintahan daerah tentu didasarkan atas perspektif dominan yang dianut para perumus UU 32/2004. Pertama, menurut para perumus UU 32/2004, dalam sistem negara kesatuan (unitarian state) tidak dikenal badan legislatif di tingkat daerah; dan badan legsilatif hanya berada di tingkat nasional (pusat). Oleh karena itu, dalam skema logika UU 32/2004, DPRD bukan lembaga legislatif daerah. Kedua, karena DPRD bukan lembaga legislatif daerah, DPRD harus didudukkan sebagai salah satu unsur penyelenggara pemerintahan daerah bersama-sama pemerintah daerah. Dengan demikian, DPRD berada dalam ranah yang sama dengan pemerintah daerah dalam struktur hubungan dengan pemerintah pusat. Dengan kata lain, DPRD berada dalam rezim pemerintahan daerah.

Apa implikasi dari rumusan kedudukan DPRD sebagai unsur penyelenggara pemerintahan daerah? Pertama, memposisikan DPRD sebagai unsur penyelenggara pemerintahan ketimbang sebagai lembaga perwakilan rakyat membuat DPRD lebih kuat secara institusional dari perspektif tata pemerintahan, tidak dari perspektif politik. Pada gilirannya, DPRD diposisikan sebagai lembaga perwakilan politik yang terlibat dalam proses politik pemerintahan. Kedua, kedudukan sebagai unsur penyelenggara pemerintahan daerah membuat posisi DPRD mengalami problem psiko-politis di hadapan pemerintah daerah sehingga mekanisme check and balances tidak bisa berjalan dengan baik. Ketiga, selain mengalami problem psiko-politis di hadapan kepala daerah, DPRD juga "lemah" secara psiko-politis di hadapan pemerintah pusat. Kedudukan sebagai unsur penyelenggara pemerintahan daerah membuat DPRD berada dalam struktur hierarkis rezim pemerintahan daerah yang dipimpin oleh Presiden. Akibat bekerjanya struktur hierarkis ini, DPRD tidak bisa melepaskan diri dari proses politik dan produk hukum yang dikeluarkan oleh Pemerintah Pusat, dalam hal ini Menteri Dalam Negeri (Mendagri).

\section{Fungsi, Tugas dan Wewenang DPRD}

Pada sisi lain, sesungguhnya DPRD lebih berfungsi sebagai lembaga pengontrol terhadap kekuasaan pemerintah daerah daripada sebagai lembaga legislatif dalam arti yang sebenarnya. Namun, dalam kenyataan sehari-hari, DPRD itu biasa disebut sebagai lembaga legislatif. DPRD, baik di daerah provinsi maupun kabupaten/kota, berhak mengajukan rancangan peraturan daerah (Raperda) kepada Gubernur-sesuai dengan yang ditentukan dalam UU 32/2004. Namun, hak inisiatif ini sebenarnya tidaklah menyebabkan posisi DPRD menjadi pemegang kekuasaan legislatif yang utama. Pemegang kekuasaan utama di bidang ini tetap ada di tangan pemerintah, dalam hal ini Gubernur atau Bupati/Walikota. ${ }^{17}$

17 Jimly Asshiddiqie, Konstitusi dan Konstitusionalisme Indonesia, (Jakarta: Sekretariat dan Kepaniteraan Mahkamah Konstitusi RI, 2006), h. 297. 
Dengan demikian, fungsi utama DPRD ialah untuk mengontrol jalannya pemerintahan di daerah, sedang berkenaan dengan fungsi legislatif, posisi DPRD bukanlah aktor yang dominan. Pemegang kekuasaan yang dominan di bidang legislatif itu tetap Gubernur dan Bupati/Walikota. Bahkan, UU 32/2004 "mewajibkan" Gubernur dan Bupati/Walikota mengajukan rancangan peraturan daerah (Raperda) dan menetapkannya menjadi Perda dengan persetujuan DPRD. Artinya, DPRD itu hanya bertindak sebagai lembaga pengendali atau pengontrol yang dapat menyetujui, menolak ataupun menyetujui dengan perubahan-perubahan, dan sesekali dapat mengajukan Raperda dengan usul inisiatif sendiri. ${ }^{18}$

Seiring dengan itu, DPRD mempunyai tugas dan wewenang:19 (i). membentuk Perda yang dibahas dengan kepala daerah untuk mendapat persetujuan bersama; (ii). membahas dan menyetujui rancangan Perda tentang APBD bersama dengan kepala daerah; (iii). melaksanakan pengawasan terhadap pelaksanaan Perda dan peraturan perundang-undangan lainnya, peraturan kepala daerah, APBD, kebijakan pemerintah daerah dalam melaksanakan program pembangunan daerah, dan kerjasama internasional di daerah; (iv). mengusulkan pengangkatan dan pemberhentian kepala daerah/wakil kepala daerah kepada Presiden melalui Menteri Dalam Negeri bagi DPRD provinsi dan kepada Menteri Dalam Negeri melalui Gubernur bagi DPRD kabupaten/kota; (v). memilih wakil kepala daerah dalam hal terjadi kekosongan jabatan wakil kepala daerah; (vi). memberikan pendapat dan pertimbangan kepada pemerintah daerah terhadap rencana perjanjian internasional di daerah; (vii). memberikan persetujuan terhadap rencana kerja sama internasional yang dilakukan oleh pemerintah daerah; (viii). meminta laporan keterangan pertanggungjawaban kepala daerah dalam penyelenggaraan pemerintahan daerah; (ix). membentuk panitia pengawas pemilihan kepala daerah; $(\mathrm{x})$. melakukan pengawasan dan meminta laporan KPUD dalam penyelenggaraan pemilihan kepala daerah; dan (xi). memberikan persetujuan terhadap rencana kerja sama antar daerah dan dengan pihak ketiga yang membebani masyarakat dan daerah.

Sebagaimana telah dikemukakan, sebagai unsur penyelenggara pemerintahan daerah, DPRD memiliki fungsi-fungsi dalam rangka mengawal berjalannya pemerintahan daerah. Fungsi tersebut mencakup fungsi legislasi, fungsi anggaran dan fungsi pengawasan..$^{20}$ Sebenarnya, lebih tepat untuk mengelompokkan fungsi-fungsi lembaga legislatif di daerah itu menjadi 3 (tiga), yaitu (i) fungsi pengawasan, (ii) fungsi legislasi, (iii) fungsi representasi. Apa yang diatur dalam Pasal 292 ayat (2) dan Pasal 343 ayat (2) UU 27/2009 mengisyaratkan bahwa DPRD sebenarnya tidak hanya menjalankan fungsi-fungsi legislasi, anggaran dan pengawasan, melainkan juga fungsi representasi. ${ }^{21}$

Fungsi-fungsi tersebut dimiliki dan dijalankan oleh DPRD dalam kerangka mengemban amanat rakyat di propinsi dan kabupaten/kota. Dapat dijelaskan bahwa fungsi legislasi adalah legislasi daerah yang merupakan fungsi DPRD untuk membentuk peraturan daerah bersama kepala daerah. Fungsi anggaran adalah fungsi

\footnotetext{
${ }^{18}$ Jimly Asshiddiqie, Konstitusi dan Konstitusionalisme Indonesia, h. 298.

${ }^{19}$ Pasal 41 ayat (1) UU 32/2004.

${ }^{20}$ Pasal 41 UU 32/2004, Pasal 292 ayat (1) dan Pasal 343 ayat (1) UU 27/2009 .

${ }^{21}$ Jimly Asshiddiqie, Pengantar Ilmu Hukum Tata Negara, (Jakarta: Konstitusi Press, 2006), h. 35.
}

8 - Jurnal Cita Hukum, Vol. II No. 1 Juni 2014. ISSN: 2356-1440. 
yang dijalankan DPRD bersama-sama pemerintah daerah untuk menyusun dan menetapkan APBD. Fungsi pengawasan adalah fungsi yang dijalankan DPRD untuk melaksanakan pengawasan terhadap pelaksanaan undang-undang, peraturan daerah dan keputusan kepala daerah serta kebijakan yang ditetapkan oleh Pemerintah Daerah. 22

Untuk menjalankan fungsi legislasi, DPRD diberikan tugas dan wewenang untuk membentuk peraturan daerah bersama Kepala Daerah. DPRD menetapkan peraturan-peraturan daerah untuk kepentingan daerah atau untuk melaksanakan peraturan perundang-undangan yang lebih tinggi tingkatannya yang pelaksanaannya didelegasikan kepada daerah. DPRD dapat membela kepentingan daerah dan penduduknya ke hadapan Pemerintah Pusat dan DPR dengan sepengetahuan Kepala Daerah yang bersangkutan. ${ }^{23}$

Dalam kaitan ini, setiap anggota DPRD diberikan hak untuk mengajukan rancangan peraturan daerah (Raperda). Di dalam UU 27/2009 memang ditemukan adanya pengertian mengenai persetujuan bersama dan mengenai fungsi legislatif DPRD bersama-sama gubernur. Kewenangan DPRD untuk memberikan persetujuan terhadap setiap Rancangan Peraturan Daerah (Raperda) itu dapat saja ditafsirkan adanya pemberikan kedudukan yang lebih tinggi atau lebih rendah atau setara kepada DPRD dalam berhadapan dengan pemerintah daerah. Pengertian "bersama-sama" tersebut berarti "kesetaraan" dan "kesederajatan". Bagaimanakah bentuk pelaksanaan prinsip persetujuan bersama dipraktikkan? Apakah persetujuan bersama dilakukan di dalam proses persidangan ataukah pada level institusional ?

Disetujui tidaknya suatu Raperda oleh DPRD, sesuai tata tertib DPRD, dilakukan melalui proses persidangan, bukan ditentukan begitu saja oleh pimpinan DPRD. Dengan sendirinya yang dimaksud dengan istilah bersama-sama tersebut dilakukan melalui persidangan bersama-sama. Dalam proses persidangan itu, bisa terjadi kemungkinan-kemungkinan. Pertama, berdasarkan mekanisme persidangan, suatu Raperda diputus melalui pemungutan suara dengan mayoritas dukungan memenangkan versi pemerintah daerah. Kedua, putusan Raperda itu justru diambil melalui pemungutan suara yang memenangkan versi partai oposisi. Dalam hal terjadi kemungkinan kedua, apakah dapat dikatakan bahwa Raperda itu sudah dibuat secara bersama-sama atau apakah pengertian persetujuan bersama itu sudah terpenuhi meskipun pihak pemerintah daerah jelas-jelas tidak menyetujuinya tetapi kalah dalam pemungutan suara. Sudah seyogyanya persetujuan bersama itu dapat dianggap sebagai persetujuan yang bersifat institusional meskipun suara yang menang adalah suara oposisi. ${ }^{24}$

Sedangkan untuk melaksanakan fungsi anggaran, DPRD diberikan wewenang untuk membahas dan memberikan persetujuan rancangan peraturan daerah mengenai anggaran pendapatan dan belanja daerah yang diajukan oleh Kepala Daerah. Sesungguhnya fungsi anggaran (budgeting) tidak tepat disebut sebagai satu

\footnotetext{
22 Nomensen Sinamo, Hukum Pemerintahan Daerah di Indonesia, h. 49.

${ }^{23}$ C.S.T. Kansil, Christine S.T. Kansil, Pemerintahan Daerah di Indonesia, (Jakarta: Sinar Grafika, 2008), h. 41

24Jimly Asshiddiqie, Format Kelembagaan Negara dan Pergeseran Kekuasaan dalam UUD 1945, (Yogyakarta: FH UII Press, 2005), h. 183.
}

Fakultas Syariah dan Hukum UIN Syarif Hidayatullah Jakarta - 9 
fungsi tersendiri. Sebab, APBD itu dituangkan dalam baju hukum Perda sehingga penyusunan APBD identik dengan pembentukan Perda tentang APBD, meskipun rancangannya selalu datang dari pihak Gubernur dan Bupati/Walikota. Sementara itu, pelaksanaan APBD itu sendiri harus pula diawasi oleh DPRD, dan pengawasan demikian termasuk kategori fungsi pengawasan yang dijalankan DPRD. 25

Sementara untuk menjalankan fungsi pengawasan, DPRD diberi tugas dan wewenang untuk melaksanakan pengawasan terhadap pelaksanaan peraturan daerah dan anggaran pendapatan dan belanja daerah. Wewenang tersebut juga dilengkapi dengan hak DPRD untuk mengajukan hak interpelasi, hak angket dan hak menyatakan pendapat. Selain itu, wewenang dan hak DPRD tersebut juga ditambah dengan hak anggota DPRD untuk mengajukan pertanyaan, meminta keterangan, mengajukan pernyataan pendapat dan mengadakan penyelidikan. ${ }^{26}$ Hak interpelasi adalah hak DPRD untuk meminta keterangan kepada Pemerintah Daerah mengenai kebijakan Pemerintah Daerah yang penting dan strategis serta berdampak luas pada kehidupan bermasyarakat dan bernegara. Hak angket adalah hak DPRD untuk melakukan penyelidikan terhadap kebijakan Pemerintah Daerah yang penting dan strategis serta berdampak luas pada kehidupan bermasyarakat dan bernegara yang diduga bertentangan dengan peraturan perundang-undangan. Hak menyatakan pendapat adalah hak DPRD untuk menyatakan pendapat terhadap kebijakan Pemerintah Daerah atau mengenai kejadian luar biasa yang terjadi di tanah air disertai dengan solusi tindak lanjut dari hak interpelasi dan hak angket. ${ }^{27}$

Pemberian hak interpelasi, hak angket, dan hak menyatakan pendapat itu terkesan sebagai bonus kepada DPRD yang kewenangan dan haknya telah direduksi oleh UU 32/2004. Menurut UU ini, DPRD hanya dapat sekadar "memanggil" Kepala Daerah untuk dimintai keterangan tanpa kewenangan memberikan sanksi. Di dalam UU ini tidak tegas dan jelas apa akibat hukum atau sanksinya jika saran atau rekomendasi DPRD tidak diindahkan oleh Kepala Daerah. ${ }^{28}$

Lebih dari itu, fungsi pengawasan DPRD menuntut DPRD untuk senantiasa mengawasi produk peraturan perundang-undangan yang dibentuk oleh pemerintah daerah. Maka dari itu, legislative review dapat diartikan sebagai proses peninjauan ulang Raperda oleh DPRD sebelum disahkan menjadi Perda. Dalam praktiknya, istilah legislative review ini tidak populer lantaran membutuhkan SDM anggota DPRD yang capable. ${ }^{29}$ Pengujian Perda melalui legislative review ini menunjukkan bahwa DPRD dalam fungsi legislasinya melakukan pengawasan terhadap Perda sehingga sebelum sebuah Raperda di-perda-kan seharusnya terlebih dahulu melewati proses kajian legislasi. Jika Raperda itu sesuai dengan peraturan perundang-undangan yang

\footnotetext{
25 Jimly Asshiddiqie, Pengantar Ilmu Hukum Tata Negara, (Jakarta: Konstitusi Press, 2006), h. 35.

${ }^{26}$ Josef Riwu Kaho, Prospek Otonomi Daerah di Negara Republik Indonesia, (Jakarta: Rajawali Press, 2007), h. 78.

27 Titik Triwulan Tutik, Konstruksi Hukum Tata Negara Indonesia Pasca Amandemen UUD 1945, (Jakarta: Kencana, 2010), h. 195.

${ }^{28}$ Nomensen Sinamo, Hukum Pemerintahan Daerah di Indonesia, (Jakarta: Pustaka Mandiri 2010), h. 51.

${ }^{29}$ Jazim Hamidi, Optik Hukum Peraturan Daerah Bermasalah, (Jakarta: Prestasi Pustakarayah, 2011), h. 123 .
} 
lebih tinggi maka ia dapat disahkan dan diundangkan; sebaliknya, jika tidak demikian maka tidak boleh disahkan. ${ }^{30}$

Selanjutnya, sebagai lembaga yang mempunyai fungsi representasi, maka setiap anggota DPRD diwajibkan untuk menyerap, menampung, menghimpun, dan menindaklanjuti aspirasi dan pengaduan masyarakat. ${ }^{31}$ Fungsi representasi ini tidak kalh pentingnya dengan fungsi-fungsi lain yang diemban DPRD. Fungsi representasi sesungguhnya merupakan parameter pertanggungjawaban politik anggota DPRD di hadapan konstituennya atau publik secara luas.

Dalam rangka menjalankan fungsi-fungsi tersebut, DPRD didukung oleh sebuah struktur yang disebut dengan alat kelengkapan DPRD. Di samping itu, DPRD juga ditopang oleh keberadaan fraksi yang merupakan struktur yang tidak termasuk bagian alat kelengkapan DPRD. Fraksi merupakan wadah berhimpunnya anggota DPRD dalam rangka mengoptimalkan pelaksanaan tugas dan wewenang serta hak dan kewajiban anggota DPRD. ${ }^{32}$

Problem peran dan fungsi DPRD bisa jadi bersumber dari UUD 1945 sendiri. UUD 1945 mengatur tentang DPRD dalam dua bab yang berbeda, yaitu Bab VI tentang Pemerintahan Daerah dan Bab VIIB tentang Pemilihan Umum. Bab VI memuat 3 (tiga) Pasal, yakni Pasal 18 (memiliki 7 ayat), Pasal 18A (memiliki 2 ayat), dan Pasal 18B (memiliki 2 ayat). Sedangkan Bab VIIB memuat 1 (satu) pasal saja, yakni Pasal 22E (memiliki 6 ayat). Dalam Bab tentang Pemerintahan Daerah (Bab VI) disebutkan bahwa pemerintahan daerah provinsi, daerah kabupaten, dan kota memiliki DPRD yang anggota-anggotanya dipilih melalui pemilihan umum. ${ }^{33}$ Sementara dalam Bab tentang Pemilihan Umum (Bab VIIB) dikatakan bahwa Pemilihan umum diselenggarakan untuk memilih anggota Dewan Perwakilan Rakyat, Dewan Perwakilan Daerah, Presiden dan Wakil Presiden dan Dewan Perwakilan Rakyat Daerah. ${ }^{34}$

Kedua aturan ini menyebabkan DPRD memiliki dua kapasitas, yakni sebagai unsur penyelenggara pemerintahan daerah (bersama kepala daerah) dan sebagai lembaga legislatif yang anggota-anggotanya dipilih melalui pemilu (bersama DPR dan DPD). Dua kapasitas ini terjelma dalam peraturan perundang-undangan yang mengatur DPRD. Sebagai unsur penyelenggara pemerintahan daerah, DPRD diatur dalam UU 32/2004, sedang sebagai lembaga legislatif yang anggota-anggotanya dipilih melalui pemilu DPRD diatur dalam UU 27/2009. Dalam praktiknya, kapasitas sebagai unsur penyelenggara pemerintahan daerah ingin lebih ditonjolkan ketimbang sebagai lembaga legislatif. Dalam kenyataannya, materi aturan tentang DPRD dalam UU 32/2004 dan UU 27/2009 saling tumpang-tindih. Hal demikian menyebabkan materi aturan tentang DPRD dalam UU 27/2009 yang menegaskan kapasitas DPRD sebagai lembaga legislatif sedikit banyak bersilang pandangan dengan materi aturan

${ }^{30}$ Jazim Hamidi, Optik Hukum Peraturan Daerah Bermasalah, h. 123. Perlu diketahui, sesungguhnya evaluasi terhadap Perda dapat dilakukan melalui 3 (tiga) mekanisme, yaitu executive review, judical review, dan legislative review. Lihat Jazim Hamidi, Optik Hukum Peraturan Daerah Bermasalah, h. 124.

31 Pasal 45 huruf (e) UU 32/2004 dan Pasal 351 UU 27/2009.

32 Pasal 301 ayat (1) UU No. 27 Tahun 2009

33 Pasal 18 ayat (3) UUD 1945 Hasil Amandemen. Pasal ini merupakan hasil amandemen kedua atas UUD 1945 yang disahkan oleh MPR pada tahun 2000.

34 Pasal 22E ayat (2) UUD 1945 Hasil Amandemen. Pasal ini merupakan hasil amandemen kedua atas UUD 1945 yang disahkan oleh MPR pada tahun 2000. 
serupa dalam UU 32/2004 yang menegaskan kapasitas DPRD sebagai unsur penyelenggara pemerintahan daerah. Seperti sudah menjadi konvensi dalam pembentukan undang-undang bahwa UU 27/2009 merupakan domainnya legislatif karena mengatur rumah tangga lembaga legislatif, sedang UU 32/2004 merupakan domainnya pemerintah (eksekutif), terutama Kementerian Dalam Negeri karena mengatur pemerintahan daerah yang merupakan lingkup kerja Kementerian Dalam Negeri.

Sesungguhnya tidak ada yang salah terkait perihal dua macam kapasitas DPRD itu. Lantaran fungsinya (legislasi, anggaran, pengawasan, dan representasi) dan cara memilih anggotanya (melalui pemilu), DPRD harus dianggap sebagai lembaga legislatif. Karena keberadaannya di daerah, DPRD juga harus menjadi unsur dari pemerintahan daerah. Dalam kaitan ini, Pasal 18B ayat (1) UUD $1945^{35}$ menyatakan bahwa hubungan wewenang antara pemerintah pusat dan pemerintahan daerah provinsi, kabupaten, dan kota, atau antara provinsi dan kabupaten dan kota, diatur dengan undang-undang dengan memperhatikan kekhususan dan keragaman daerah. Sedangkan Pasal 18B ayat (2) menegaskan bahwa hubungan keuangan, pelayanan umum, pemanfaatan sumber daya alam dan sumber daya lainnya antara pemerintah pusat dan pemerintahan daerah diatur dan dilaksanakan secara adil dan selaras berdasarkan undang-undang.

DPRD dibentuk, baik di daerah provinsi maupun di daerah kabupaten/kota. DPRD disebut sebagai lembaga yang menjalankan kekuasaan legislatif di daerah. Akan tetapi, harus dicatat bahwa fungsi legislatif di daerah tidaklah sepenuhnya berada di tangan DPRD seperti fungsi DPR dalam hubungannya dengan Presiden, yakni sebagaimana ditentukan dalam Pasal 20 ayat (1) jo. Pasal 5 ayat (1) UUD 1945 Hasil Amandemen. Dalam Pasal ini ditetapkan bahwa DPR memegang kekuasaan membentuk UU; dan bahwa Presiden berhak mengajukan RUU kepada DPR. Sedangkan kewenangan menetapkan Peraturan Daerah (Perda), baik daerah provinsi maupun kabupaten/kota, tetap berada di tangan Gubernur dan Bupati/Walikota dengan persetujuan DPRD. Karena itu, dapat dikatakan bahwa Gubernur dan Bupati/Walikota tetap merupakan pemegang kekuasaan eksekutif sekaligus legislatif, meskipun pelaksanaan fungsi legislatif itu harus dilakukan dengan persetujuan DPRD yang merupakan lembaga pengontrol terhadap kekuasaan pemerintahan di daerah. ${ }^{36}$

UUD 1945 tidak memerintahkan pengaturan hubungan lembaga-lembaga selain eksekutif (presiden) di tingkat pusat dengan lembaga-lembaga di tingkat daerah. Akibatnya, DPRD sebagai lembaga legislatif di daerah tidak memiliki hubungan dengan DPR dan DPD di tingkat pusat. Padahal, sebagai lembaga yang sama-sama berada di pohon legislatif, penting untuk diatur hubungan DPRD dengan DPR dan DPD, misalnya dalam hal penyaluran aspirasi publik. Bila rakyat di daerah menyalurkan aspirasi ke DPRD, tidak semua aspirasi tersebut bisa ditangani atau menjadi domain DPRD. Aspirasi yang berkenaan dengan mekanisme pengambilan

\footnotetext{
${ }^{35}$ Pasal 18B UUD 1945 Hasil Amandemen. Pasal ini merupakan hasil amandemen kedua atas UUD 1945 yang disahkan oleh MPR pada tahun 2000.

36 Jimly Asshiddiqie, Konstitusi dan Konstitusionalisme Indonesia, (Jakarta: Sekretariat dan Kepaniteraan Mahkamah Konstitusi RI, 2006), h. 296-297.
}

12 - Jurnal Cita Hukum, Vol. II No. 1 Juni 2014. ISSN: 2356-1440. 
keputusan di tingkat lokal tentu menjadi kewenangan DPRD untuk memberikan solusinya. Namun, bila aspirasi tersebut berkenaan dengan pengambilan keputusan di tingkat nasional, tentu aspirasi tersebut harus disampaikan ke lembaga aspirasi di tingkat pusat, baik DPR maupun DPD. Pada titik ini penting dibuat saluran dari DPRD ke DPR dan DPD. Faktanya, saluran aspirasi tersebut belum pernah ada sehingga DPRD pun menyampaikan aspirasinya kepada pemerintah pusat (eksekutif pusat). Hal ini makin menyebabkan pemerintah pusat dominan terhadap DPRD. Fakta konstitusional ini mengisyaratkan pentingnya perubahan UUD 1945 dengan visi menguatkan otonomi daerah pada umumnya dan penguatan DPRD pada khususnya.

Pada titik ini menarik untuk disimak usulan perubahan UUD 1945 yang digagas oleh Dewan Perwakilan Daerah (DPD). Dalam hal hubungan pusat-daerah, DPD mengusulkan agar yang diatur tidak hanya hubungan antara pemerintah pusat dan pemerintahan daerah (DPRD dan kepala daerah), melainkan hubungan antara pusat (tanpa kata "pemerintah") dan daerah (tanpa kata "pemerintahan"). ${ }^{37}$ Argumentasi DPD dapat dilihat dalam catatan kaki terhadap Pasal 34 ayat (1) Naskah Amandemen UUD 1945 yang dibuat oleh Kelompok DPD-MPR, sebagaimana berikut. ${ }^{38}$

"Ayat 1 ini menyatakan dengan tegas pola hubungan yang dapat diatur adalah pola hubungan antara pusat dan daerah, bukan hanya antara pemerintah pusat dan pemerintahan daerah. Ayat ini menegaskan bahwa pada prinsipnya bukanlah pemerintah pusat yang membagi kewenangan negara/pusat ke daerah, tetapi antara negara (national) dengan daerah (subnational) melalui legislatif pusat, yakni DPR dan DPD. Kendatipun demikian, dalam membuat UU yang mengatur pola hubungan tersebut, DPR dan DPD harus memperhatikan kekhususan dan keragaman daerah. Penguatan DPRD versi DPD juga dilakukan dengan mengeluarkan DPRD sebagai bagian dari pemerintahan daerah. Tidak disebutkan lagi bahwa "pemerintahan" daerah memiliki DPRD sebagaimana tercantum dalam Pasal 18 ayat (3) Perubahan Kedua UUD 1945 melainkan cukup "daerah memiliki DPRD dan seterusnya."39

Penguatan selanjutnya adalah pencantuman tiga fungsi DPRD dalam konstitusi, yaitu fungsi legislasi, fungsi anggaran dan fungsi pengawasan. ${ }^{40}$ Dalam hal pembentukan peraturan daerah, naskah perubahan UUD 1945 versi DPD secara tegas menyatakan bahwa yang memiliki kewenangan untuk menetapkan peraturan daerah adalah DPRD. ${ }^{41}$ Sedangkan pemerintah daerah hanya berwenang untuk mengajukan rancangan peraturan daerah. ${ }^{42}$

\footnotetext{
${ }^{37}$ Lihat Pasal 34 ayat (1) Naskah Amandemen UUD 1945 versi DPD, (Jakarta: DPD, 2008)

38 Tim DPD-MPR, Naskah Amandemen Undang-Undang Dasar Negara Republik Indonesia Tahun 1945, (Jakarta: DPD, 2008), h. 14.

${ }^{39}$ Pasal 38 ayat (1) Naskah Amandemen UUD 1945 versi DPD, Tim DPD-MPR, Naskah Amandemen Undang-Undang Dasar Negara Republik Indonesia Tahun 1945.

40 Pasal 38 ayat (2) Naskah Amandemen UUD 1945 versi DPD, Tim DPD-MPR, Naskah Amandemen Undang-Undang Dasar Negara Republik Indonesia Tahun 1945.

41 Pasal 38 ayat (3) Naskah Amandemen UUD 1945 versi DPD, Tim DPD-MPR, Naskah Amandemen Undang-Undang Dasar Negara Republik Indonesia Tahun 1945.

42 Pasal 36 ayat (3) Naskah Amandemen UUD 1945 versi DPD, Tim DPD-MPR, Naskah Amandemen Undang-Undang Dasar Negara Republik Indonesia Tahun 1945.
} 
Dikaitkan dengan penguatan DPRD, tentu tidak bisa dengan hanya menunggu perubahan UUD 1945. Peluang perubahan peraturan perundang-undangan di bawah UUD 1945 harus dimanfaatkan dengan sebaik-baiknya. UU MD3 adalah instrumen yang dapat digunakan untuk memperkuat posisi DPRD, terutama sebagai lembaga legislatif di daerah. Sedapat mungkin hal-hal yang berkenaan dengan DPRD diselesaikan melalui kehadiran UU yang mengatur perihal DPRD. Pengaturan lebih lanjutnya-bila dirasakan perlu-cukup diatur dengan peraturan daerah atau tata tertib DPRD yang keduanya merupakan produk DPRD sendiri. Tidak sepatutnya hal-hal yang berkaitan dengan DPRD yang merupakan lembaga legislatif diatur oleh eksekutif, meskipun eksekutif di tingkat pusat. Lembaga legislatif harus memiliki otonomi penuh untuk mengatur rumah tangganya sendiri. Seandainya terjadi penyimpangan akibat otonomi tersebut, lembaga yudikatif yang akan menghukumnya sehingga tidak ada lagi peluang bagi eksekutif untuk mengaduk-aduk institusi DPRD.

Secara teoretis, di antara dua undang-undang yang mengatur perihal DPRD, yakni UU MPR, DPR, DPD, dan DPRD (selanjutnya disebut UU MD3) dan UU Pemerintahan Daerah (selanjutnya disebut UU Pemda), UU MD3 inilah yang harus diberikan perhatian lebih besar. Hal-hal yang berkenaan dengan rumah tangga DPRD harus diatur lebih rinci dalam UU MD3, bukan UU Pemda. Alasannya, UU MD3 lebih menonjolkan karakter DPRD sebagai lembaga legislatif, sedang UU Pemda lebih menguatkan karakter DPRD sebagai unsur dari penyelenggara pemerintahan daerah.

Meskipun tidak diperintahkan pengaturannya oleh UUD 1945, UU MD3 bisa saja mengatur pola hubungan DPRD dengan DPR dan DPD dalam hal penyampaian aspirasi dari daerah ke pusat. Pola hubungan ini penting diatur agar ada garis penyambung antara lembaga aspirasi rakyat di tingkat lokal dan lembaga aspirasi rakyat di tingkat nasional. Selama ini pola hubungan itu tidak tercipta sehingga kesan berjalan sendiri-sendiri memang terasa menonjol. UU Pemda nantinya lebih banyak mengatur pola hubungan antara kepala daerah dan DPRD. Pola hubungan seperti ini jelas tidak mungkin diatur dalam UU MD3 karena UU ini hanya diperuntukkan bagi lembaga yang berada di ranah kekuasaan legislatif. Ringkasnya, untuk penguatan DPRD dalam tingkat undang-undang, UU MD3 akan mengatur rumah tangga DPRD dan pola hubungan DPRD dengan lembaga legislatif pusat (DPR dan DPD). Sementara UU Pemda hanya mengatur hubungan DPRD dengan kepala daerah (gubernur dan bupati/walikota).

Lalu bagaimana dengan instrumen peraturan pemerintah, peraturan presiden dan peraturan menteri? Ketiga instrumen eksekutif (executive order) tersebut sepatutnya tidak lagi mengatur DPRD. Pengaturan tentang DPRD harus diserahkan kepada DPRD sendiri, baik melalui instrumen perda maupun tata tertib DPRD. Asumsinya, DPRD sendirilah yang mengerti akan kebutuhannya, bukan lembaga di luar dirinya. Kendati demikian, UU MD3 dan UU Pemda harus memberikan batasan-batasan yang jelas agar DPRD tidak seenaknya dalam membuat peraturan. Misalnya, dalam hal otonomi untuk menentukan renumerasi para anggota DPRD, kedua UU itu dapat menentukan bahwa jumlahnya tidak boleh lebih besar daripada renumerasi anggota DPR dan DPD, atau sekian persen dari renumerasi anggota DPR dan DPD. Kedua UU itu bisa juga menentukan bahwa usul kenaikan pendapatan 
hanya diberlakukan untuk DPRD periode berikutnya dengan alasan agar tidak terjadi conflict of interests. Pengaturan yang sama juga bisa diberlakukan bagi DPR dan DPD. ${ }^{43}$

\section{Keanggotaan DPRD}

Sebagai implementasi Pasal 18 ayat (3) UUD 1945, ditegaskan dalam UU 27/2009 bahwa DPRD terdiri atas anggota partai politik peserta pemilu yang dipilih melalui pemilihan umum. Ketentuan tersebut sekaligus memastikan bahwa tidak satu pun anggota DPRD yang tidak berasal dari partai politik atau tidak satu pun anggota DPRD yang dipilih melalui jalur perseorangan. Pembatasan oleh UU 27/2009 ini telah menutup rapat peluang perseorangan untuk ikut dalam proses pemilihan anggota DPRD.44 Sementara itu, dalam Pasal 22E ayat (2) UUD 1945 dinyatakan bahwa pemilihan umum diselenggarakan untuk memilih anggota Dewan Perwakilan Rakyat, Dewan Perwakilan Daerah, Presiden dan Wakil Presiden dan Dewan Perwakilan Rakyat Daerah. Seiring dengan itu, Pasal 22E ayat (3) menegaskan bahwa peserta pemilihan umum untuk memilih anggota Dewan Perwakilan Rakyat dan anggota Dewan Perwakilan Rakyat Daerah adalah partai politik. ${ }^{45}$

Jumlah anggota DPRD dibatasi, paling sedikit 35 orang dan sebanyak-banyaknya 100 orang untuk DPRD Propinsi. Sedangkan untuk jumlah anggota DPRD kabupaten/kota paling sedikit 20 orang dan paling banyak 50 orang. ${ }^{46}$ Jumlah anggota DPRD untuk masing-masing daerah berbeda-beda menurut kuota yang ditentukan UU 27/2009. Perihal keanggotaan DPRD juga diatur dalam UU No. 10 Tahun 2008 tentang Pemilihan Umum Anggota DPR, DPD, DPRD Propinsi dan DPRD Kabupaten/Kota (selanjutnya disebut UU 10/2008). Parameter yang digunakan untuk menentukan berapa orang jumlah anggota DPRD untuk suatu daerah ialah jumlah penduduk di daerah bersangkutan. ${ }^{47}$

Keanggotaan DPRD disahkan atau diresmikan dengan keputusan Menteri Dalam Negeri untuk DPRD Propinsi dan dengan keputusan Gubernur untuk keanggotaan DPRD Kabupaten/Kota. Setiap anggota DPRD memiliki masa jabatan selama 5 (lima) tahun sejak dilantik dan berakhir pada saat anggota DPRD yang baru mengucapkan sumpah/janji. ${ }^{48}$

Dalam rangka mengoptimalkan pelaksanaan fungsi, tugas dan wewenang DPRD, serta hak dan kewajiban anggota DPRD, dibentuk fraksi sebagai wadah berhimpun anggota DPRD. ${ }^{49}$ Setiap fraksi di DPRD beranggotakan paling sedikit

43 Lihat Pasal 24 Naskah Amandemen UUD 1945 versi DPD, Tim DPD-MPR, Naskah Amandemen Undang-Undang Dasar Negara Republik Indonesia Tahun 1945.

44 Pasal 290 UU 27/2009 menyatakan bahwa DPRD provinsi terdiri atas anggota partai politik peserta pemilihan umum yang dipilih melalui pemilihan umum. Sedangkan Pasal 341 UU 27/2009 menyatakan bahwa DPRD kabupaten/kota terdiri atas anggota partai politik peserta pemilihan umum yang dipilih melalui pemilihan umum.

45 Pasal 22E UUD 1945 Hasil Amandemen. Pasal ini merupakan hasil amandemen ketiga dari UUD 1945, yang disahkan pada tahun 2001.

46 Lihat Pasal 294 ayat (1) dan Pasal 345 ayat (1) UU 27/2009.

47 Lihat Pasal 23 ayat (2) dan Pasal 26 ayat (2) UU 10/2008.

${ }^{48}$ Lihat Pasal 294 ayat (2) dan Pasal 352 ayat (4) dan Pasal 345 ayat (2) UU 27/2009.

${ }^{49}$ Lihat Pasal 301 ayat (1) dan Pasal 352 ayat (1) UU 27/2009. 
sama dengan jumlah komisi di DPRD tersebut. ${ }^{50}$ Apabila sebuah partai politik yang jumlah anggotanya sama atau lebih dari jumlah komisi, maka partai politik tersebut dapat membentuk satu fraksi. ${ }^{51}$

Namun, apabila sebuah partai tidak memiliki anggota sebanyak jumlah komisi di DPRD maka partai tersebut harus bergabung dengan fraksi lain atau bergabung dengan partai politik lain untuk membentuk sebuah fraksi. Sedangkan bila tidak satupun partai politik yang jumlah anggotanya memenuhi batas minimal pembentukan fraksi maka partai politik yang ada dapat membentuk fraksi gabungan, dengan catatan bahwa jumlah fraksi gabungan -di DPRD tersebut-paling banyak 2 (dua) fraksi. 52

\section{Alat Kelengkapan DPRD}

Adapun alat kelengkapan DPRD terdiri atas: (i) Pimpinan, (ii) Badan Musyawarah, (iii) Komisi, (iv) Badan Legislasi Daerah, (v) Badan Anggaran, (vi) Badan Kehormatan, dan (vii) alat kelengkapan lain yang diperlukan dan dibentuk oleh rapat paripurna. Dalam menjalankan tugasnya, alat kelengkapan dibantu oleh sekretariat. ${ }^{53}$ Masing-masing alat kelengkapan DPRD tersebut tidak diatur secara rinci dalam UU 27/2009, kecuali perihal Pimpinan DPRD. Perihal tata cara pembentukan, susunan serta tugas dan wewenang alat kelengkapan DPRD didelegasikan untuk diatur sendiri oleh DPRD.

Sebagai salah satu alat kelengkapan DPRD, pimpinan DPRD tentunya memiliki sejumlah tugas dan fungsi. Walaupun demikian, UU 27/2009 ternyata tidak mengatur secara rinci tugas dan fungsi pimpinan DPRD. UU ini hanya mengatur komposisi pimpinan DPRD serta tatacara pengisian jabatan tersebut. Pengaturan tentang tugas dan wewenang Pimpinan DPRD -sebagai bagian dari alat kelengkapan DPRD- justru dimandatkan untuk diatur lebih lanjut dalam peraturan DPRD tentang tata tertib. ${ }^{54}$

Sekalipun tugas dan wewenang pimpinan tidak diatur secara rinci dalam UU 27/2009, UU ini mengatur soal pengisian jabatan pimpinan DPRD. Dibandingkan dengan aturan UU 22/2003 yang menentukan pimpinan DPRD dipilih dari dan oleh anggota DPRD, UU 27/2009 mengubah aturan tata cara pengisian jabatan yang demikian. Jelasnya, pimpinan DPRD tidak lagi dipilih, tetapi langsung ditentukan harus berasal dari partai politik yang memperoleh suara terbanyak dalam pemilihan umum. Jabatan ketua mesti diisi oleh wakil partai politik yang memperoleh suara terbanyak pertama. Sedangkan wakil ketua DPRD berasal dari partai politik yang memperoleh suara terbanyak kedua, ketiga dan/atau keempat. ${ }^{55}$

\section{Penutup}

Kunci keberhasilan penyelenggaraan pemerintahan daerah adalah kemampuan DPRD dalam menjalankan tiga plus fungsi utamanya-legislasi, anggaran dan

\footnotetext{
${ }^{50}$ Lihat Pasal 301 ayat (3) dan Pasal 352 ayat (3) UU 27/2009.

51 Lihat Pasal 301 ayat (4) dan Pasal 352 ayat (4) UU 27/2009.

${ }^{52}$ Lihat Pasal 301 ayat (5), ayat (6), ayat (7) dan Pasal 352 ayat (5), ayat (6), ayat (7) UU 27/2009.

${ }^{53}$ Lihat Pasal 302 ayat (1) dan ayat (2) dan Pasal 353 ayat (1) dan ayat (2) UU 27/2009.

${ }^{54}$ Lihat Pasal 302 ayat (3) dan Pasal 353 ayat (3) UU 27/2009.

${ }^{55}$ Lihat Pasal 303 ayat (3) dan Pasal 354 ayat (3) UU 27/2009.
}

16 - Jurnal Cita Hukum, Vol. II No. 1 Juni 2014. ISSN: 2356-1440. 
pengawasan, dan plus representasi-secara simultan, proporsional dan berkelanjutan. Fungsi-fungsi tersebut dikenal sebagai fungsi-fungsi lembaga legislatif. Oleh karena itu, tidaklah berlebihan jika dikatakan bahwa keberhasilan atau kegagalan demokrasi perwakilan bisa ditunjukkan melalui efektivitas anggota parlemen dalam menjalankan fungsinya. Dalam konteks pengalaman berdemokrasi yang belum matang, bekerjanya fungsi lembaga DPRD masih memerlukan usaha perbaikan terus menerus dan dukungan yang memadai dari sistem pendukung DPRD.

Menyadari konsekuensi yang bisa timbul dari proses delegitimasi DPRD, di masa mendatang penting untuk memperkuat struktur dan kelembagaan DPRD melalui 3 (tiga) agenda berikut. Pertama, memperjelas dan memperkuat kedudukan DPRD sebagai badan legislatif. Kedua, memperkuat kewenangan DPRD. Ketiga, memperkuat kapasitas DPRD dalam menjalankan fungsi-fungsinya.

Dalam kaitannya dengan DPRD, revisi UU 27/2009 harus memuat beberapa ketentuan baru, antara lain: (i) pengakuan hak recall masyarakat atas anggota DPD; (ii) penegasan fungsi rumah aspirasi; (iii) penegasan DPD berkantor (beraktifitas) di daerah; (iv) mekanisme penyerapan aspirasi rakyat di daerah; dan (v) pelonggaran persyaratan pengajuan RUU oleh DPD.

Dalam kaitannya dengan proses pembentukan UU Pemilukada (Pemilihan Umum Kepala Daerah) dan revisi UU 32/2004 paling tidak terdapat beberapa agenda penting yang perlu menjadi catatan dalam proses pembentukan kedua undang-undang tersebut. Pertama, penguatan kewenangan DPRD harus diarahkan untuk mempertegas pinsip kedaulatan rakyat (demokrasi) serta asas-asas desentralisasi dan otonomi luas. Kedua, untuk memperkuat mekanisme check and balances antar lembaga pemerintahan di daerah, kewenangan DPRD dalam menjalankan fungsi legislasi dan anggaran perlu diimbangi dengan kewenangan kepala daerah untuk menggunakan hak veto ketika muncul rancangan peraturan daerah yang merupakan usul inisiatif DPRD. Ketiga, untuk memperkuat kewenangan DPRD dalam menjalankan fungsi pengawasan, dalam RUU Pemilukada perlu dicantumkan larangan rangkap jabatan berupa jabatan kepala daerah/wakil kepala terpilih yang disandingi dengan jabatan struktural yang bersangkutan di partai politik.

\section{Pustaka Acuan}

Asshiddiqie, Jimly, Format Kelembagaan Negara dan Pergeseran Kekuasaan dalam UUD 1945, Yogyakarta: FH UII Press, 2005

Asshiddiqie, Jimly, Konstitusi dan Konstitusionalisme Indonesia, Jakarta: Sekretariat dan Kepaniteraan Mahkamah Konstitusi RI, 2006

Asshiddiqie, Jimly, Pengantar Ilmu Hukum Tata Negara, Jakarta: Konstitusi Press, 2006

Tim DPD-MPR, Naskah Amandemen Undang-Undang Dasar Negara Republik Indonesia Tahun 1945, Jakarta: DPD, 2008

Fauzan, Muhammad, Hukum Pemerintahan Daerah: Kajian tentang Hubungan Keuangan antara Pusat dan Daerah, Yogyakarta: UII Press, 2006

Hamidi, Jazim, Optik Hukum Peraturan Daerah Bermasalah: Menggagas Peraturan Daerah yang Responsif dan Berkesinambungan, Jakarta: Prestasi Pustakarayah, 2011 
Haris, Syamsuddin, (et.al), Membangun Format Baru Otonomi Daerah, Jakarta: LIPI Press, 2006

Huda, Ni'matul, Hukum Tata Negara Indonesia, Jakarta; Rajawali Press, 2005

Kansil, C.S.T., Christine S.T. Kansil, Pemerintahan Daerah di Indonesia, Jakarta: Sinar Grafika, 2008

Kusnardi, Moh., Harmaily Ibrahim, Pengantar Hukum Tata Negara Indonesia, Jakarta: PSHTN-UI dan CV Sinar Bakti, 1983.

Mahfud MD, Moh., Perdebatan Hukum Tata Negara Pasca Amandemen Konstitusi, Jakarta: LP3ES, 2007

Murhani, Suriansyah, Aspek Hukum Pengawasan Pemerintah Daerah, Malang: Laksbang Mediatama, 2008

Setyanto, Widya P., Halomoan Pulungan, (eds.), Ada Apa dengan 10 Tahun Otonomi Daerah (Dinamika Politik Lokal di Indonesia), Salatiga: Persemaian Cinta Kemanusiaan (Percik), 2011

Sinamo, Nomensen, Hukum Pemerintahan Daerah di Indonesia, Jakarta: Pustaka Mandiri 2010

Tutik, Titik Triwulan, Konstruksi Hukum Tata Negara Indonesia Pasca Amandemen UUD 1945, Jakarta: Kencana, 2010 
